Abstracta Iranica Abstranica

Revue bibliographique pour le domaine irano-aryen

Volume 31 | 2011

Comptes rendus des publications de 2008

\title{
« Aqa Najafi, Haj Aqa Nurullah, and the Emergence of Islamism in Isfahan 1889-1908 ». Iranian Studies, 41/2, 2008, p. 155-172.
}

Denis Hermann

\section{(2) OpenEdition}

Journals

\section{Édition électronique}

URL : http://journals.openedition.org/abstractairanica/39601

DOI : 10.4000/abstractairanica.39601

ISSN : 1961-960X

Éditeur :

CNRS (UMR 7528 Mondes iraniens et indiens), Éditions de l'IFRI

\section{Édition imprimée}

Date de publication : 15 mai 2011

ISSN : 0240-8910

Référence électronique

Denis Hermann, « «Aqa Najafi, Haj Aqa Nurullah, and the Emergence of Islamism in Isfahan

1889-1908 ». Iranian Studies, 41/2, 2008, p. 155-172. », Abstracta Iranica [En ligne], Volume 31 | 2011 document 179, mis en ligne le 11 octobre 2012, consulté le 05 octobre 2020. URL : http:// journals.openedition.org/abstractairanica/39601; DOI : https://doi.org/10.4000/abstractairanica 39601

Ce document a été généré automatiquement le 5 octobre 2020.

Tous droits réservés 


\section{« Aqa Najafi, Haj Aqa Nurullah, and the Emergence of Islamism in Isfahan 1889-1908 ». Iranian Studies, 41/2, 2008, p. 155-172.}

\section{Denis Hermann}

1 Cet article complète très utilement une série de publications récentes sur l'histoire du mouvement constitutionnel à Ispahan (voir nos c.r. pour la Nouvelle Revue des Études Iraniennes, 1, 2008, p. 221-223 ; Iranian Studies, 42/3, 2009, p. 514-518 ; c.r. $\mathrm{n}^{\circ} 225$ dans Abs. Ir., 29, 2006) qui restait encore récemment relativement méconnue. Ispahan fut pourtant particulièrement mobilisée contre la régie des tabacs en 1891-92. C'est aussi dans cette ville qu'a été fondée en 1899 la Šerkat-e Eslāmiyye, qui a jeté en Iran les bases théoriques et pratiques de la quête d'autosuffisance économique (Hodkafā'̄i).

2 L'A. revient ici sur deux figures locales du mouvement constitutionnel : Āqā Najafī Eṣfahānī (m. 1332/1914) et Ḥājj Āqā Nūr Allāh Eṣfahānī (m. 1306š./1927). V.M. insiste en particulier sur l'intérêt qu'accordèrent ces deux mojtahed aux idéaux panislamistes et sur l'implication de Nūr Allāh Eșfahānī dans la fondation d'un comité (anjoman) local appelé à jouer un rôle fondamental dans l'organisation des forces proconstitutionnelles d'Ispahan.

3 Cet article est essentiellement basé sur l'analyse de rapports du ministère des Affaires étrangères britannique de l'époque ainsi que sur la littérature politique composée par ces deux acteurs, en particulier le Moqīm va mosāfer d'Ḥājj Āqā Nūr Allāh Eșfahānī. 
INDEX

Thèmes : 4.3. Histoire de l'Iran moderne (à partir de 1905)

\section{AUTEURS}

DENIS HERMANN

CNRS - Mondes iranien et indien - Paris 